\title{
実環境における水素侵入を再現するための水素添加法
}

\author{
大村朋彦 \\ 日本製鉄株式会社 鉄鋼研究所 \\ J. Japan Inst. Met. Mater. Vol. 84, No. 9 (2020), pp. 285-294 \\ (C) 2020 The Japan Institute of Metals and Materials \\ Overview
}

\section{Hydrogen Charging Methods for Simulating Hydrogen Entry from Actual Environments}

Tomohiko Omura

Steel Research Laboratory, Nippon Steel Corporation, Futtsu 293-8511

\begin{abstract}
Researches on appropriate hydrogen charging methods for simulating hydrogen absorption in low alloy steels, stainless steels and high $\mathrm{Ni}$ alloy, from actual environments were overviewed. Both absorbed hydrogen concentrations and hydrogen desorption profiles were compared between various hydrogen charging conditions using thermal desorption analysis (TDA) on hydrogen-charged samples. For low alloy steels, immersion or cathodic hydrogen charging in aqueous solutions were appropriate for simulating hydrogen absorption from atmospheric corrosion or high pressure gaseous hydrogen environments. Absorbed hydrogen concentration could be controlled by adding appropriate amount of hydrogen-promoter or adjusting cathodic current density and applied potential in aqueous solutions. Comparisons in TDA profiles showed that the ratio of strongly-trapped hydrogen and weakly-trapped hydrogen changed depending upon the total amount of absorbed hydrogen. This result means the state of hydrogen in steels can change according to the amount of absorbed hydrogen. For stainless steels or high Ni alloy, cathodic hydrogen charging in aqueous solutions was appropriate for simulating high pressure gaseous hydrogen environments or galvanic coupling conditions. TDA profiles apparently differed depending on hydrogen charging temperature or duration. However, numerical simulation indicated that these profiles were decided by initial hydrogen distribution in specimens, not by trapped hydrogen, contrary to low alloy steels. [doi:10.2320/jinstmet.J2020009]
\end{abstract}

(Received March 16, 2020; Accepted June 15, 2020; Published August 25, 2020)

Keywords: hydrogen embrittlement, low alloy steel, stainless steel, nickel alloy, immersion test, cathodic charging, cyclic corrosion test, high pressure hydrogen

\section{1. 緒言}

水素脆化は種々の金属材料で起こり得るが1), 高強度の鉄 鋼材料で特に大きな問題となる ${ }^{2,3)}$. 水素脆化の多くは外部 環境から材料中に侵入する水素により引き起こされる ${ }^{2,3)}$. よって, 水素脆化の評価は実験室内で試験片に水素を添加 し, さらに必要に応じて応力やひずみを加える方法により行 われる ${ }^{3)}$. 金属材料への水素添加法には, 水溶液中への浸 漬 ${ }^{3)}$ や水溶液中で試験片を分極し試験片上で水素発生を起こ させる陰極水素チャージ4,5) などが挙げられる。 ただし，水 素脆化特性の適正な評価には，材料の実使用環境における水 素侵入を再現できる水素添加法が必要となる. すなわち, 実 験室内の水素添加が実環境と比べてどの程度厳しいのか, 実 環境を適正に再現する水素チャージ法は何か, を把握する必 要がある.

本報では，低合金鋼，ステンレス鋼，高合金を用いて種々 の方法で水素添加を行い, 実環境における水素侵入を再現す るための水素添加法を検討した研究例を概説する.

\section{2. 低 合 金 鋼}

低合金鋼は種々の環境で使用されるが, 高力ボルトなどの
高強度鋼は大気環境において遅れ破壊と呼ばれる水素脆化を 起こすことが広く知られている ${ }^{3)}$ 。遅れ破壊の評価には, 酸 浸漬試験が過去多く行われている3). また, PC (Pre-stressed Concrete) 鋼棒もコンクリート環境で水素脆化を起こし, こ の評価には, Fédération Internationale de la Précontrainte(FIP) 浴6) と呼ばれるチオシアン酸アンモニウム $\left(\mathrm{NH}_{4} \mathrm{SCN}\right)$ 水溶液 への浸漬試験が多く用いられる。 これらの試験では腐食反応 を使って鋼材表面に水素を発生させ，その水素を鋼材中に侵 入させる. 一方, 櫛田らは鋼材を腐食させることなく水素を 添加する方法として, 陰極電解法による遅れ破壊の評価法を 提案した ${ }^{4)}$. 隙間部や孔食底の $\mathrm{pH}$ が 3.5 程度まで低下し得 ることを考虑し, $\mathrm{pH} 3.5$ の酸環境における水素侵入を陰極水 素チャージにより再現する方法である. 山崎らは, 鋼材が遅 れ破壊を起こさない最大の水素濃度 (限界水素濃度)を陰極 チャージ後の定荷重試験により求め, 環境からの吸蔵水素濃 度と比較し, その大小関係に基づき実ボルトの遅れ破壊を評 価する方法を提案した ${ }^{5)}$. 㓌極チャージには水素侵入促進の 目的で $\mathrm{NH}_{4} \mathrm{SCN}$ を加えた水溶液を用いて, 電流密度や時間 を制御し, 所望の量の水素を鋼材に添加する. 環境からの吸 蔵水素濃度には, 乾湿繰り返し試験を行い鋼材中に吸蔵され た水素濃度を測定し用いている.

水素脆化が問題となるその他の用途としては, $\mathrm{NH}_{4} \mathrm{SCN}$ と 同様に水素侵入促進作用を持つ硫化水素 $\left(\mathrm{H}_{2} \mathrm{~S}\right)$ を含む湿潤環 
境で用いられる油井管 ${ }^{7,8)}$ やラインパイプ, 燃料電池自動車 に水素を供給する水素ステーションに設置される蓄圧器 ${ }^{9,10)}$ などが挙げられる。

諸分野における材料の高強度化に伴い, 水素脆化の研究は 活況を見せており，2009-2012 年の間，日本鉄鋼協会にて 「水素脆化研究の基盤構築」研究会が実施された ${ }^{11)}$ 。その中 の A グループでは「水素脆化を適正に評価できる水素添加法 の提案」を目標に活動が行われ，共通素材を用いて多数の研 究機関が種々の方法で水素チャージと水素分析を行う共同研 究を実施した ${ }^{12-15)}$ 。以下にその成果の中から，低合金鋼の 共通素材を用いて種々の水素添加法により実環境からの水素 侵入の再現を検討した結果を紹介する ${ }^{12)}$.

共通素材には，引張強さが $1100 \mathrm{MPa}$ 級の $\mathrm{Cr}-\mathrm{Mo}$ 含有鋼 (JIS-SCM435 鋼, $0.35 \% \mathrm{C}-0.8 \% \mathrm{Mn}-1.1 \% \mathrm{Cr}-0.15 \% \mathrm{Mo}$, 数值は重量\%を示す)ならびに引張強さが $1400 \mathrm{MPa}$ 級の $\mathrm{Cr}-\mathrm{Mo}-\mathrm{V}$ 鋼 $\left(0.4 \% \mathrm{C}-0.7 \% \mathrm{Mn}-1.2 \% \mathrm{Cr}-0.65 \% \mathrm{Mo}^{-} 0.30 \% \mathrm{~V}\right)$ を 用いた。いずれも焼入れ焼戻し処理により強度を調整し，焼 戻しマルテンサイト組織を有する鋼である. $\mathrm{Cr}-\mathrm{Mo}$ 鋼につ いては，焼入れ焼戻し後に冷間伸線した材料(予ひずみ材)も 評価に供した。供試材から直径 $8 \mathrm{~mm}$, 長さ $30 \mathrm{~mm}$ の試験片 を採取し，600 番エメリー紙まで研磨を行った後に，以下に 述べる浸漬試験, 陰極チャージ試験, 乾湿繰り返し試験 (Cyclic Corrosion Test, CCT), 高圧水素ガス中の曝露試験, に供した．浸漬試験および㓌極チャージ試験は人為的に制御 された水素添加法, $\mathrm{CCT}$ および高圧水素ガス中の曝露試験 は実環境における水素吸蔵を評価する方法に相当する.

浸漬試験には，前述の FIP 浴 ${ }^{6)}$ および塩酸を用いた，FIP 浴中の浸漬には, $50^{\circ} \mathrm{C}$ の $20 \% \mathrm{NH}_{4} \mathrm{SCN}$ 水溶液を用いた。塩 酸浸漬試験には常温の $0.36 \%(0.1 \mathrm{~N})$ 塩酸と $5 \%(1.4 \mathrm{~N})$ 塩酸 の 2 種の溶液を用いた。陰極チャージ試験には，常温の $3 \%$ $\mathrm{NaCl}$ 水溶液, および $3 \mathrm{~g} / \mathrm{L}$ の $\mathrm{NH}_{4} \mathrm{SCN}$ を加えた $3 \% \mathrm{NaCl}$ 水
溶液を用いて，カソード電流密度を $0.01-1 \mathrm{~mA} / \mathrm{cm}^{2}$ の範囲で 制御した定電流試験，または電位を $-0.9 〜-1.5 \mathrm{~V}$ (vs. 飽和 $\mathrm{Ag} / \mathrm{AgCl}$ 電極) の範囲で制御した定電位試験を $48 \mathrm{~h}$ の期間 行った. CCT ではJASO M 609-91 ${ }^{16)}$ の規定に従い，塩水噴 霧 $\left(35^{\circ} \mathrm{C}, 5 \% \mathrm{NaCl}\right) 2 \mathrm{~h}$, 乾燥 $\left(60^{\circ} \mathrm{C}, \mathrm{RH} 20-30 \%\right) 4 \mathrm{~h}, \quad$ 湿潤 $\left(50^{\circ} \mathrm{C}\right.$ ，RH95\%以上) $2 \mathrm{~h}$ の繰り返し試験を最長 $336 \mathrm{~h}$ の期間 行った。高圧水素ガス中曝露試験では，水素圧 $98 \mathrm{MPa}$ およ び $140 \mathrm{MPa}$ ，温度 $85^{\circ} \mathrm{C}$ のオートクレーブ中に試験片を 1000 $\mathrm{h}$ の期間曝露した，燃料電池自動車や水素ステーションにお ける金属材料の使用は通常, 温度の上限は $85^{\circ} \mathrm{C}$, 水素ガス 圧は最大で $100 \mathrm{MPa}$ 程度であり，それらを考慮して曝露試 験条件を決定した。いずれの試験においても試験直後の試験 片は，水素の逃散を防止するため液体窒素または $-80^{\circ} \mathrm{C} の$ 冷 凍庫にて保管した。 その後, 試験片中に吸蔵された水素濃度 を昇温脱離法により測定した。水素分析前にはエメリー紙を 用いて試験片を研磨し，アセトン洗浄，乾燥を行った。分析 器にはガスクロマトグラフもしくは四重極質量分析装置を用 いた。

Fig. 1 に種々の条件で水素チャージを行った試験片の昇温 脱離水素分析曲線を示す. Fig. 1(a) は FIP 浴中浸漬試験, Fig. 1 (b) は陰極チャージ試験, Fig. 1 (c) はCCT, Fig. 1 (d) は 高圧水素中曝露試験である. Fig. 1(a)-Fig. 1(d) に共通の特 徵として, $\mathrm{Cr}-\mathrm{Mo}$ 鋼無ひずみ材のピーク温度が最も低いこ と, $\mathrm{Cr}-\mathrm{Mo}$ 鋼の予ひずみ材は複数のピークを持つこと, $\mathrm{Cr}-\mathrm{Mo}^{-} \mathrm{V}$ 鋼は $\mathrm{Cr}-\mathrm{Mo}$ 鋼無ひずみ材よりもピーク温度が高く $\mathrm{Cr}-\mathrm{Mo}$ 鋼予ひずみ材と同様に約 $300^{\circ} \mathrm{C}$ まで水素放出があるこ と，が挙げられる。また， $\mathrm{Cr}-\mathrm{Mo}$ 鋼予ひずみ材の特徵とし て, ピーク形状が各チャージ法間で異なることが確認され た.すなわち, Fig. 1 (b) および Fig. 1 (c) では高温側 $\left(250^{\circ} \mathrm{C}\right)$ のピークが低温側 $\left(100-150^{\circ} \mathrm{C}\right)$ のピークより高く, Fig. 1 (a) および Fig. 1 (d) では逆に低温側のピークが高温側のピーク
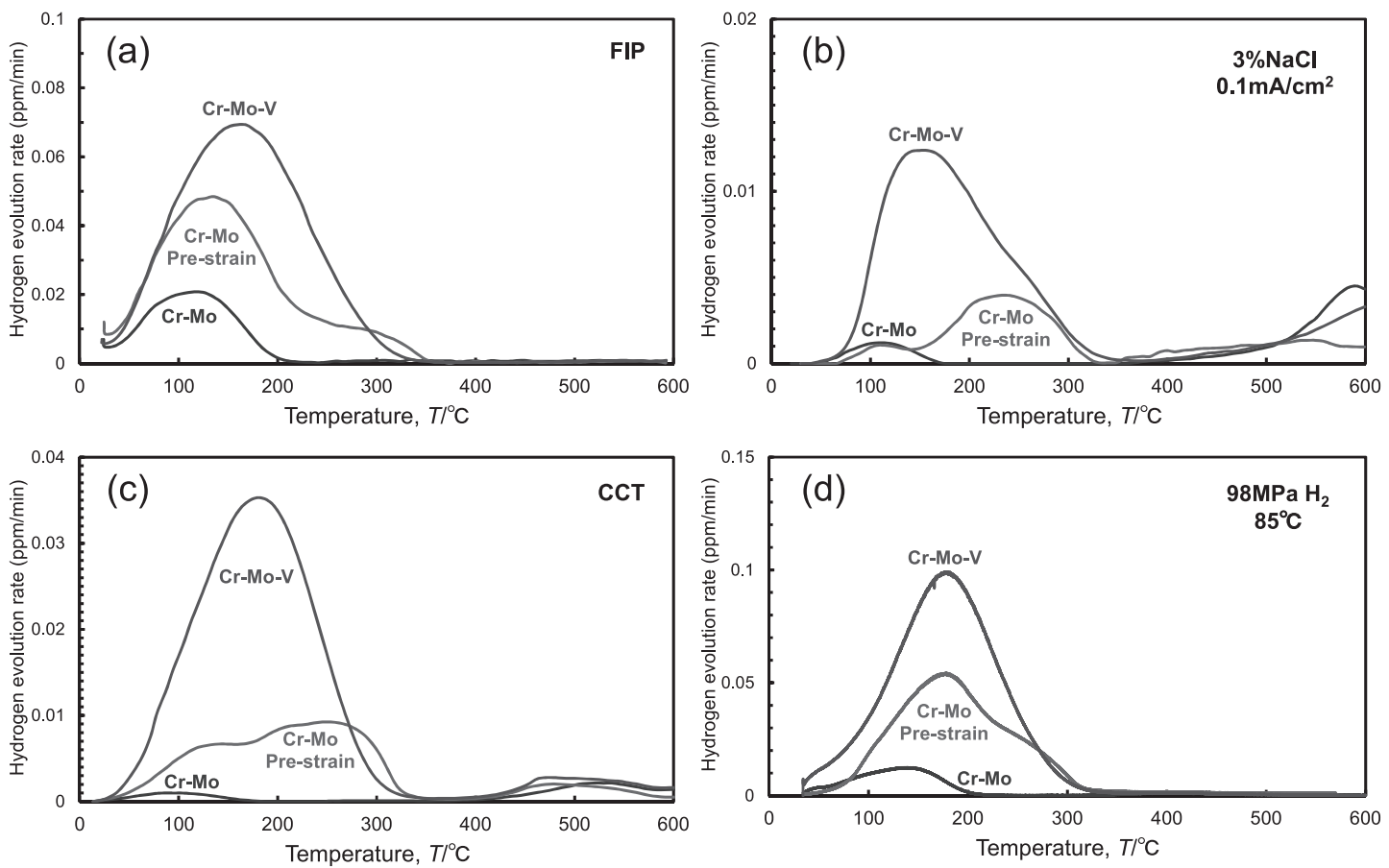

Fig. 1 Profiles of thermal desorption analysis of hydrogen at $100^{\circ} \mathrm{C} / \mathrm{h}$ : (a) FIP, (b) cathodic charging, (c) CCT, (d) high pressure $\mathrm{H}_{2}$. 
より高かった。この機構は, 昇温脱離曲線の数值解析により 以下のように説明されている13). Fig. 1(b)や Fig. 1(c)の条件 は吸蔵される総水素濃度が少なく, まず $250^{\circ} \mathrm{C}$ の高温側の卜 ラップサイトに優先的に水素が充填される. 一方, Fig. 1 (a) や Fig. 1(d)のように総水素濃度が多い条件では, $250^{\circ} \mathrm{C}$ のト ラップサイトが水素で飽和した後に，より低温側の 100$150^{\circ} \mathrm{C}$ のイトにも水素がトラップされる。低温側 (100$150^{\circ} \mathrm{C}$ ) の水素放出ピークは転位 (水素との結合エネルギー 27 $\mathrm{kJ} / \mathrm{mol})$, 高温側 $\left(250^{\circ} \mathrm{C}\right)$ の水素放出ピークは空孔(結合エネ ルギー $41.5 \mathrm{~kJ} / \mathrm{mol})$ への水素トラップを反映すると推察され ている ${ }^{13)}$ ，すなわち，材料によっては水素濃度に応じて水 素の存在状態が変化する場合があることに注意を要する.

Fig. 1 の昇温脱離曲線で, 常温から第一ピークの放出完了 温度 $\left(350^{\circ} \mathrm{C}\right)$ までの水素を積分し，これを室温拡散性水素濃 度と解䣋した。ただし， $\mathrm{Cr}-\mathrm{Mo}$ 鋼予ひずみ材については, 前述の低温および高温ピークの両方を含む值となる. Fig. 1 (a)の浸漬試験, Fig. 1(c)のCCT, Fig. 1 (d)の高圧水素ガス 中曝露試験による水素濃度については後述するが, まず Fig. 1(b)の陰極チャージによる水素濃度を Fig. 2 によとた. Fig. 2 には定電流および定電位の陰極チャージ試験の両方の 結果を併記した。下横軸は定電流試験におけるカソード電流 密度であり, 相当するデー夕点は Fig. 2 中の大きなマークで ある. カソード電流密度の増加に伴い水素濃度は増加した。 溶液中に水素侵入促進の触媒 $\left(\mathrm{NH}_{4} \mathrm{SCN}\right)$ が無い場合 (Open マーク)に比べ, $\mathrm{NH}_{4} \mathrm{SCN}$ を加えると (Solid マーク) 水素濃度 は増加した。また, $\mathrm{Cr}-\mathrm{Mo}$ 鋼無ひずみ材, $\mathrm{Cr}-\mathrm{Mo}$ 鋼予ひず み材, $\mathrm{Cr}-\mathrm{Mo}-\mathrm{V}$ 鋼の順に水素濃度は増加した. 上横軸は定 電位試験における電位を示し, 相当するデー夕点は Fig. 2 中 の小さなマークである. 電位の低下により水素濃度は増加し た. $\mathrm{NH}_{4} \mathrm{SCN}$ および材質の影響についても, 定電流試験と同 様の傾向を示した。 なお，定電流試験の際の電位変化や，定 電位試験の際のカソード電流密度も別途記録しており，各溶 液や各材質について, Fig. 2 に示す下横軸と上横軸の対応を 示すことが確認されている.よって, 適切な水溶液の選定, およびカソード電流密度もしくは電位の設定により, 各供試 材に狙いの量の水素を吸蔵させることができる.

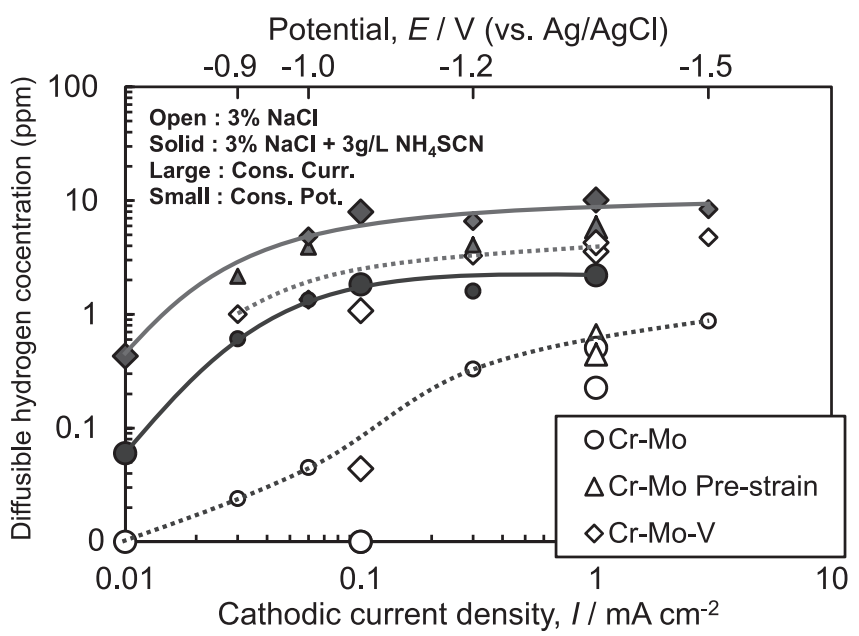

Fig. 2 Effect of cathodic current density and applied potential on hydrogen absorption under cathodic hydrogen charging.
Fig. 3 に各種水素チャージ法による吸蔵水素濃度を比較し た。塩酸 $(\mathrm{HCl})$ 浸漬試験および FIP 試験については，最長 96 $\mathrm{h}$ までの試験を行い，測定された飽和值もしくは最大值を Fig. 3 にはプロットした. 上下のバンドは測定機関間の測定 值の差異を示す。塩酸浸漬試験は $0.36 \%(0.1 \mathrm{~N})$ 塩酸と $5 \%$ $(1.4 \mathrm{~N})$ 塩酸の 2 条件で実施したが，水素濃度に大きな差は 無かった ${ }^{12)}$ ため, Fig. 3 には両方の結果をまとめて示した. 陰極チャージ試験の上下のバンドは誤差ではなく, Fig. 2 に 示した人為的に可変な範囲を示す. CCT では試験期間(乾湿 の繰り返し数)の増加に伴っていずれの鋼種においても水素 濃度は経時的に増加したが， $336 \mathrm{~h}$ の時点で水素濃度は飽和 傾向にあることが確認されている12). $336 \mathrm{~h}$ を超えた期間の 試験は行っていないが, $336 \mathrm{~h}$ 以降に水素濃度が大きく増加 することはないと予想されたため, $336 \mathrm{~h} の$ 試験後の值を Fig. 3 にはプロットした. 高圧水素ガス中の曝露試験は水素 圧 $98 \mathrm{MPa}$ および $140 \mathrm{MPa}$ の 2 条件で行っており, 両方の結 果を Fig. 3 には示したが, 両者の值は非常に近かった ${ }^{12)}$ 。こ の試験では試験時間を $1000 \mathrm{~h}$ としたが，素材の水素拡散係 数を考慮すると試験片の中心部まで水素は充填されてお $\eta^{12)}, 1000 \mathrm{~h}$ を超えて試験をしても水素濃度は Fig. 3 と同等 と推定される.

Fig. 3 から, 鋼材の実使用環境として大気腐食環境を想定 し, 大気腐食模擬環境 $(\mathrm{CCT})$ における水素吸蔵を再現する水 素チャージ方法としては，塩酸浸漬または $3 \% \mathrm{NaCl}$ 中陰極 チャージが適当である，塩酸浸漬については，前述のように $0.36 \%(0.1 \mathrm{~N})$ 塩酸と $5 \%(1.4 \mathrm{~N})$ 塩酸の 2 条件で水素濃度に差 が無かったため, どちらの溶液を用いても良いが，Fig. 3 に バンドで示すばらつきが生じた。また， $\mathrm{Cr}-\mathrm{Mo}$ 鋼無ひずみ 材では, 塩酸浸漬の方が CCTよりも多くの水素を吸蔵した. 㓌極チャージについては, CCT における水素吸蔵を再現す る具体的な条件は Fig. 2 から導かれる。例えば $\mathrm{Cr}-\mathrm{Mo}$ 無ひ ずみ材では $3 \% \mathrm{NaCl}$ 中の定電位 $-0.9 \sim-1.0 \mathrm{~V}$ (vs. 飽和 $\mathrm{Ag} /$ $\mathrm{AgCl}$ 電極) もしくは定電流 0.03-0.1 mA/ $\mathrm{cm}^{2}$ が, $\mathrm{Cr}-\mathrm{Mo}^{-} \mathrm{V}$ 鋼や $\mathrm{Cr}-\mathrm{Mo}$ 鋼予ひずみ材では $3 \% \mathrm{NaCl}$ 中の定電位 -1.0 $-1.2 \mathrm{~V}$ (vs. 飽和 $\mathrm{Ag} / \mathrm{AgCl}$ 電極) もしくは定電流 0.1-1 mA $/ \mathrm{cm}^{2}$ が，それぞれ適切な条件となる。 $\mathrm{NH}_{4} \mathrm{SCN}$ を含む溶液中で

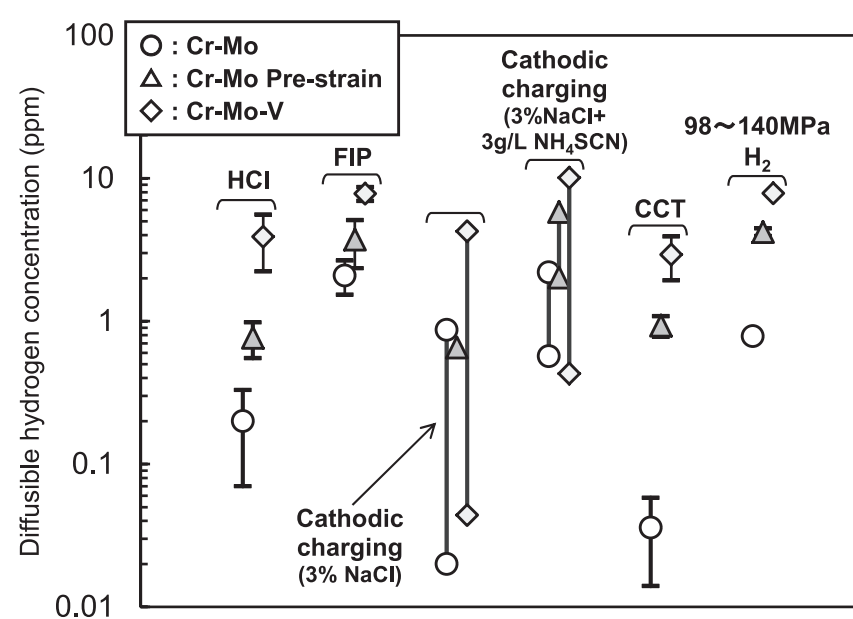

Fig. 3 Comparison in absorbed hydrogen concentration between hydrogen charging methods. 
も，より高電位もしくは低電流とすることで CCTにおける 水素吸蔵を再現することは可能だが, Fig. 2 からわかるよう にこれらの条件は水素濃度の変動が大きい領域に相当し, 水 素濃度のばらつきが大きくなる可能性がある。 また, 試験時 間については塩酸浸漬および陰極チャージともに, 素材の水 素拡散係数と寸法(厚さや径)を考慮し, 試験片の中心部まで 水素を充填できる時間以上であれば良いと考えられる.

高圧水素ガス中曝露試験ではさらに多量の水素が吸蔵さ れ、これを再現するには FIP 浴または $\mathrm{NH}_{4} \mathrm{SCN}$ を添加した 溶液中での陰極チャージが適切である．FIP 浴は, $\mathrm{Cr}-\mathrm{Mo}$ 鋼 予ひずみ材および $\mathrm{Cr}-\mathrm{Mo}^{-} \mathrm{V}$ 鋼では, 高圧水素ガス環境にお ける水素侵入量を再現できている，ただし， $\mathrm{Cr}-\mathrm{Mo}$ 鋼無ひ ずみ材では, FIP 浴では高圧水素ガス環境よりも多くの水素 を吸蔵した，ただし，FIP 浴では $\mathrm{NH}_{4} \mathrm{SCN}$ の濃度を変化させ ることにより, 水素濃度を変化させることも可能であ $\eta^{17,18)}, \mathrm{Cr}-\mathrm{Mo}$ 鋼無ひずみ材では $\mathrm{NH}_{4} \mathrm{SCN}$ の濃度を低減す ることで, 高圧水素ガス環境からの水素吸蔵を再現できると 推定される。 $\mathrm{NH}_{4} \mathrm{SCN}$ を添加した溶液中での陰極チャージに ついては，具体的な最適条件は Fig. 2 から導かれ，例えば $\mathrm{Cr}-\mathrm{Mo}$ 無ひずみ材では定電位 $-0.9 \sim-1.0 \mathrm{~V}$ (vs. 飽和 $\mathrm{Ag}$ / $\mathrm{AgCl}$ 電極) もしくは定電流 $0.03-0.1 \mathrm{~mA} / \mathrm{cm}^{2}$ が, $\mathrm{Cr}-\mathrm{Mo}-\mathrm{V}$ 鋼や $\mathrm{Cr}-\mathrm{Mo}$ 鋼予ひずみ材では定電位 $-1.0 \sim-1.5 \mathrm{~V}$ (vs. 飽和 $\mathrm{Ag} / \mathrm{AgCl}$ 電極) もしくは定電流 0.1-1 $\mathrm{mA} / \mathrm{cm}^{2}$ が，それぞれ 適切な条件となる。

いずれの水素チャージ条件においても， Cr-Mo 鋼無ひず み材に対して, 予ひずみ材の水素濃度は高かった。 ひずみ付 与は転位や空孔の密度を増加させ, 転位や空孔が水素トラッ プサイトとして働くことがこの理由と考えられる，Vを含有 させた $\mathrm{Cr}-\mathrm{Mo}-\mathrm{V}$ 鋼は，無ひずみでも $\mathrm{Cr}-\mathrm{Mo}$ 鋼予ひずみ材以 上の水素を吸蔵した. V 系の微細炭化物が水素をトラップす る効果 ${ }^{4,5)}$ がこの理由と推定される. ただし, Fig. 3 からわか るように, 水素濃度が少ないチャージ法 $(\mathrm{HCl}$ 浸漬, $3 \% \mathrm{NaCl}$ 水溶液中の陰極チャージ, CCT) では各材質の水素濃度の違 い(比率)が大きいのに比べて, 水素濃度が多いチャージ法 (FIP 浴中浸漬, $\mathrm{NH}_{4} \mathrm{SCN}$ 入り溶液中の陰極チャージ, 高圧 水素ガス中の曝露試験) では各材質の違いは小さい.この理 由には前述のように, 水素濃度が少ないチャージ法では, $\mathrm{Cr}-\mathrm{Mo}$ 鋼予ひずみ材や $\mathrm{Cr}-\mathrm{Mo}-\mathrm{V}$ では安定な (昇温脱離曲線 で高温側にピークがある)サイトに水素がトラップされ，そ の効果により $\mathrm{Cr}-\mathrm{Mo}$ 鋼よりも顕著に水素濃度が増すことが 考えられる.すなわち, 安定なトラップサイトに水素を補足 し水素脆化を防止する手法は, 吸蔵水素濃度が低い場合に有 効であることが示唆される. 逆に水素濃度が多いチャージ法 では安定なトラップサイトが早期に飽和し, 各材質間の水素 濃度の違いが小さくなると考えられる。

\section{3.ステンレス鋼}

ステンレス鋼は一般に耐食性に優れ, 腐食に伴う水素侵入 の懸念はほとんど無いが，水素ガス環境で使用された場合に は水素脆化の可能性がある。この現象は水素環境脆化 (Hydrogen Environment Embrittlement) または水素ガス脆化
(Hydrogen Gas Embrittlement) と呼ばれる ${ }^{19-21)}$ 。近年，来るべ き水素社会の到来に向け, 水素を燃料として走行する燃料電 池自動車や，高圧の水素ガスを貯蔵または供給する水素ス テーションの実用化研究が進められており，2 章に述べた低 合金鋼とともに, ステンレス鋼もこれらの用途に広く使用さ れている，水素ガス脆化の評価には，高圧の水素ガス環境中 で機械試験を行う方法 ${ }^{22-25)}$ や, 高温高圧の水素ガス中に試 験片を曝露して水素を吸収させ, その試験片を取り出した後 に大気中で機械試験を行う方法 ${ }^{26-30)}$ がある。後者は厳密に は吸収した水素による可逆的な水素脆化(水素を逃散させれ ば脆化は起こらない) という意味で, 内部可逆水素脆化 (Internal Reversible Hydrogen Embrittlement) ${ }^{19)}$ と呼ばれる。こ れらの高圧水素ガスに起因した脆化に関しても, 外部環境か らの水素侵入に着目した解析や, それを再現した評価法が重 要となる ${ }^{31-33)}$. 前述の鉄鋼協会の研究会において, ステン レス鋼に関しても陰極チャージ試験と高圧水素ガス中の曝露 試験の対比が行われており ${ }^{14,15)}$, 種々の条件の陰極チャージ 試験により高圧水素ガス環境からの水素吸蔵の再現を検討し た結果を以下に紹介する14).

共通素材には安定オーステナイト系ステンレス鋼の SUS316L および準安定オーステナイト系ステンレス鋼の SUS304 の市販の固溶化熱処理板を用いた。いずれも厚さは $0.77 \mathrm{~mm}$ である.ひずみの影響の調査のため, 無ひずみ材に 加えて $10 \%$ および $40 \%$ の引張ひずみを付与した子ひずみ材 も試験に供した。なお，透磁率測定およびX線回折により， 304 の 40\%予ひずみ材ではひずみ誘起マルテンサイトが生成 していることが確認されている14,15)。㓌極チャージについて は, 2 章の低合金鋼と同様に常温の $3 \% \mathrm{NaCl}$ 水溶液および 3 $\mathrm{g} / \mathrm{L}$ の $\mathrm{NH}_{4} \mathrm{SCN}$ を加えた $3 \% \mathrm{NaCl}$ 水溶液を用いて, カソー ド電流密度 0.1-10 mA/ $\mathrm{cm}^{2}$ の定電流試験, 保持電位 - 1.0 $-1.5 \mathrm{~V}$ (vs. $\mathrm{Ag} / \mathrm{AgCl}$ )の定電位試験を $48 \mathrm{~h}$ の期間行った。高 圧水素ガス中の曝露試験については, 水素圧 $98 \mathrm{MPa}$-温度 $250^{\circ} \mathrm{C}$-試験時間 $72 \mathrm{~h}$, 水素圧 $98 \mathrm{MPa}$-温度 $85^{\circ} \mathrm{C}$-試験時間 $1000 \mathrm{~h}$, 水素圧 $140 \mathrm{MPa}$-温度 $85^{\circ} \mathrm{C}$-試験時間 $1000 \mathrm{~h}$ の 3 条 件で行った. 試験後には 2 章と同様の要領で試験片を冷凍保 管した後に, 昇温脱離法により吸蔵水素濃度を測定した.

Fig. 4 に昇温脱離曲線の例を示す. Fig. 4(a)は 316L の陰極 チャージ試験, Fig. 4(b)は 316Lの高圧水素ガス中の曝露試 験後の分析結果を示す．無ひずみ材，10\%ひずみ材，40\%ひ ずみ材の間に，顕著な差は見られなかった。ただし，Fig. 4 (a) と Fig. 4(b) を比較すると曲線の形状が大きく異なった. また, Fig. 4(c) は304の陰極チャージ試験, Fig. 4(d) は304 の高圧水素ガス中の曝露試験後の分析結果を示す。 304 無ひ ずみ材および 10\%ひずみ材は, Fig. 4(a) および Fig. 4(b)の 316L と同様の傾向を示した. 一方, 304 の 40\%ひずみ材は 特異な形状を示し, Fig. 4(c)では無ひずみ材や 10\%ひずみ 材よりも高い值(多い水素濃度)となり, Fig. 4(d)では無ひず み材や $10 \%$ ひずみ材と曲線形状(ピーク温度)が異なってい た。これらの挙動はいずれも，以下に述べるように昇温脱離 曲線の数值解析に基づき説明できる ${ }^{15)}$.

まず, Fig. 4(a) と Fig. 4(b)の違いの機構は以下のように説 明できる. 面心立方 (face centered cubic, fcc)構造のオーステ 
ナイト相では水素拡散係数は非常に小さいため, 水素添加条 件によっては試験片の厚さ方向に水素濃度の分布を生じる. 水素濃度分布は, 水素拡散係数, 試験時間, 試験片厚さに応 じて決まり ${ }^{34)}$, 水素濃度の厚さ方向の分布を計算 ${ }^{32,33)}$ する と Fig. 5 となる.ただし, Fig. 5 の縦軸は表面水素濃度を 1 としたときの相対值, 横軸は試験片厚さを 2 とした場合の相 対位置を示す. $316 \mathrm{~L}$ と 304 の水素拡散係数には, どちらも $4.41 \times 10^{-3} \exp (-53510 / R T)\left(\mathrm{cm}^{2} / \mathrm{s}\right)^{35)}$ の值を用いた。 $R$ は気 体定数 $(8.31 \mathrm{~J} / \mathrm{mol}), T$ は温度 $(\mathrm{K})$ である. 2 章および後述の 4 章における議論も同様の考え方に基づいているが, 試験片 の最表面は速やかに環境と平衡する水素濃度に到達し, 試験 片中の平均水素濃度は, 試験片の中心部まで水素が充填され る時間で決まる. Fig. 5 (a) は常温の陰極チャージ試験の場合 の水素濃度分布を示す。この試験は常温で短期間で行ってい るため, 水素は試験片の中心部には到達できず, 表面に局在 化する. Fig. 5 (b) は $85^{\circ} \mathrm{C}$ の高圧水素ガス中の曝露試験の場 合の分布を示す。この試験では表面近傍の水素濃度が高いも
のの，試験片の中心部にもある程度の水素が浸透している. 図示略すが, $98 \mathrm{MPa}$ 水素-温度 $250^{\circ} \mathrm{C}-72 \mathrm{~h}$ の試験では, 試 験片の内部まで完全に水素が充填されている結果となる。こ れらの初期水素濃度分布と水素拡散係数の温度依存性に基づ き, 昇温脱離曲線の数值解析が可能である ${ }^{15)}$. 計算の結果, Fig. 5(a)のサンプルを昇温すると速やかに水素は脱離し, Fig. 4 (a)のように低温 $\left(100^{\circ} \mathrm{C}\right.$ 近傍 $)$ にピークを示すことが示 されている. 一方, Fig. 5(b)のサンプルを昇温すると, Fig.

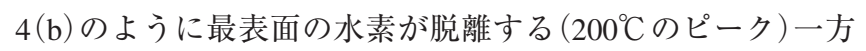
で, 最表面の一部の水素は試験片の内部に移動し, 少し遅れ て再び試験片の最表面に再移動し, 試験片から放出される $\left(350^{\circ} \mathrm{C}\right.$ のピーク). 図示略すが, $98 \mathrm{MPa}$ 水素-温度 $250^{\circ} \mathrm{C}-72$ $\mathrm{h}$ の曝露材では, 昇温脱離分析では高温 $\left(350^{\circ} \mathrm{C}\right.$ ピーク)での 放出のみが見られる。 これらの計算から, Fig. 4(a) と Fig. 4 (b)の昇温脱離曲線の形状の違いは試験片中の初期水素濃度 分布の違いのみで決まっており, 2 章の低合金鋼のような水 素トラップ状態の違いを反映しているわけではないことが結
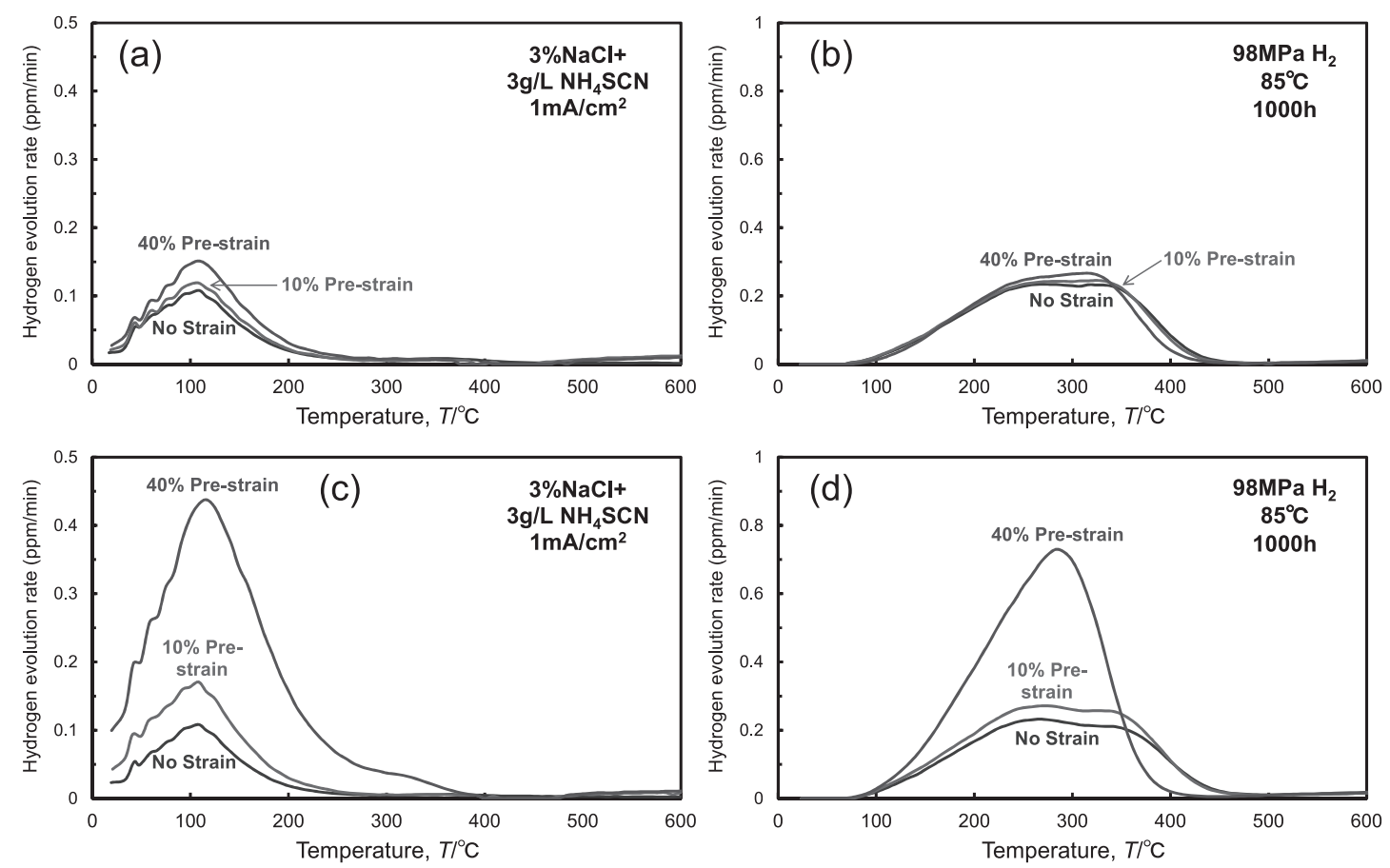

Fig. 4 Profiles of thermal desorption analysis of hydrogen at $100^{\circ} \mathrm{C} / \mathrm{h}$ : (a) - (b) Type 316L, (c) - (d) Type 304.
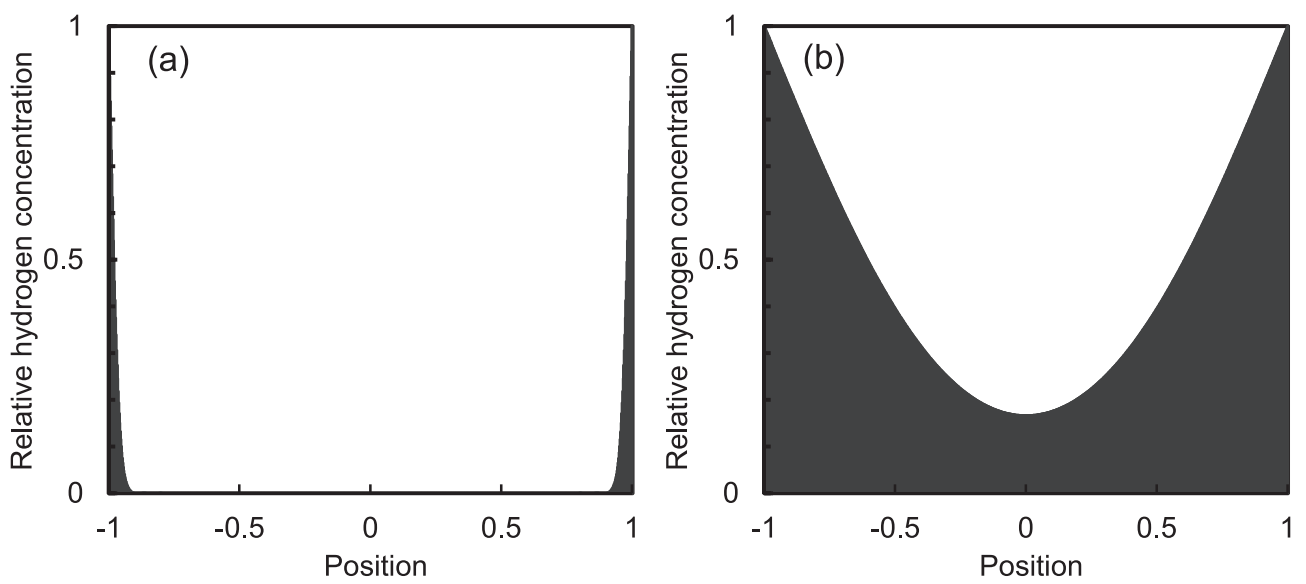

Fig. 5 Distribution of hydrogen in a plate specimen: (a) cathodic charging at RT for $48 \mathrm{~h}$, (b) exposure in $98 \mathrm{MPa} \mathrm{H}_{2}$ at $85^{\circ} \mathrm{C}$ for $1000 \mathrm{~h}$. 
論付けられている ${ }^{15)}$ 。なお, SUS316L および $\mathrm{Ni}$ 基合金を用 いた検討で，試験片の厚さと水素チャージの温度および時間 を同一にすると，陰極水素チャージと高圧水素ガス中の曝露 試験で昇温脱離曲線は同形状になることが確認されてい る $^{36)}$.

Fig. 4 (c) と Fig. 4(d)の 304 の 40\%予ひずみ材の特異な挙 動も，同様の解析で説明できる ${ }^{15)}$. 304 の $40 \%$ ひずみ材で はひずみ誘起マルテンサイト相が生じており, これが水素の 拡散パスとして㗢くと考えられる。実際に 304 の冷間加工材 を用いた水素透過試験では, 冷間加工により水素拡散係数が

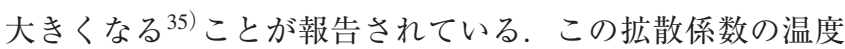
依存性 ${ }^{35)}$ を用いて昇温脱離分析曲線の数值解析を行うと,

Fig. 4(c) と Fig. 4(d)の 304 の 40\%予ひずみ材の放出曲線が 再現できる ${ }^{15)}$.

Fig. 4 の昇温脱離曲線で, 常温からの第一ピークの放出完 了温度 $\left(450^{\circ} \mathrm{C}\right)$ までの水素を積分し, この值を吸蔵水素濃度 とした。まず，Fig. 4(a) および Fig. 4(c)の陰極チャージ試験 による水素濃度を Fig. 6 にまとめた. Fig. 6 は 304 および 316L の，いずれも無ひずみ材を用いた定電流密度および定 電位の試験結果である. Fig. 2 と同様に, 下横軸は定電流試 験におけるカソード電流密度であり, 相当するデー夕点は Fig. 6 中の大きなマークである. カソード電流密度の増加に 伴い水素濃度は増加した。 また, $\mathrm{NH}_{4} \mathrm{SCN}$ 無しの溶液中 (Open マーク)よりも, $\mathrm{NH}_{4} \mathrm{SCN}$ を加えた溶液中 (Solid マー ク)では水素濃度は増加した. 316L と 304 の間に顕著な差は 認められなかった。 上横軸は定電位試験における電位を示 し, 相当するデー夕点は Fig. 6 中の小さなマークである. 電 位の低下により水素濃度は増加し, $\mathrm{NH}_{4} \mathrm{SCN}$ の影響について も定電流試験と同様であった，低合金鋼と同様に，別途実施 したカソード分極試験により, 下横軸の電流密度と上横軸の 電位は Fig. 6 の対応を示すことが確認されている.よって, 適切な溶液の選定と, カソード電流密度もしくは電位の設定 により，狙いの量の水素を吸蔵させることができる.

Fig. 7 に高圧水素ガス中の曝露試験による水素濃度を, 陰 極チャージ試験と比較して示す。横軸は予ひずみ量である. Fig. 7 中の大マークは高圧水素ガス中の曝露試験, 小マーク

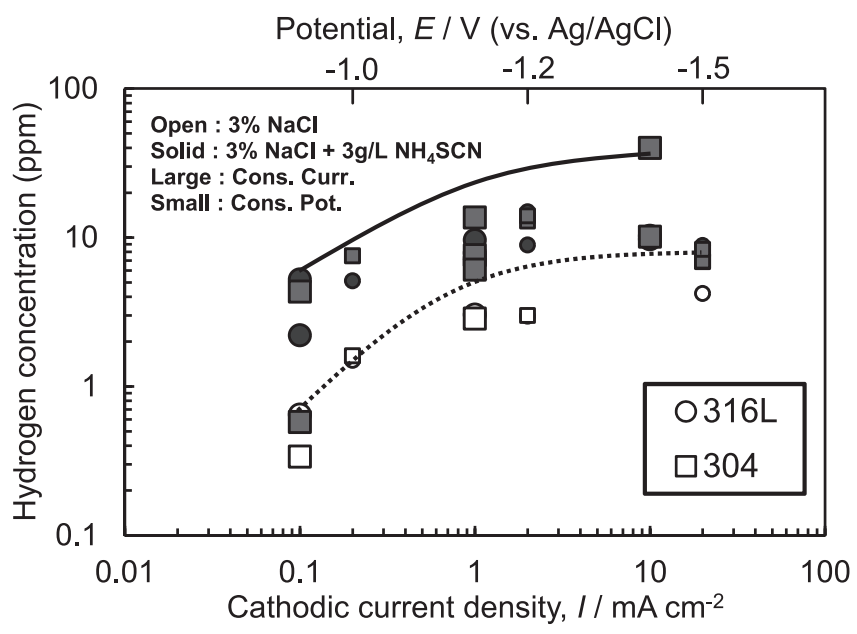

Fig. 6 Effect of cathodic current density and applied potential on hydrogen absorption under cathodic hydrogen charging.
は陰極チャージ試験の結果を示す。大マークの Open は 98 $\mathrm{MPaH}_{2}-85^{\circ} \mathrm{C}-1000 \mathrm{~h}$, Solid は $98 \mathrm{MPaH}_{2}-250^{\circ} \mathrm{C}-72 \mathrm{~h}$ の条件の 試験結果である。 小マークの Open は $3 \% \mathrm{NaCl}$ 水溶液中の定 電流試験, Solid は $\mathrm{NH}_{4} \mathrm{SCN}$ を加えた $3 \% \mathrm{NaCl}$ 水溶液中の定 電流試験の結果である。まず，大マークの高圧水素ガス中の 曝露試験に比べ，小マークの陰極チャージ試験では，水素濃 度は低くなった。試験片中の水素は Fig. 5 の分布をしている と推定され, Fig. 7 の縦軸はFig. 5 の濃度分布を持つ試験片 で測定された平均水素濃度である。よって, Fig. 5 の最表層 の水素濃度を比較すると, Fig. 7 とは異なる傾向を示す可能 性があり，詳細は後述する。また，各材質の挙動の違いとし て，316L は高圧水素ガス中曝露試験および㓌極チャージ試 験の両方において，予ひずみの影響は小さいことがわかる. オーステナイト系の材料では, 水素の格子間固溶による結合 エネルギーが大きく，転位との結合エネルギーは小さいと言 われており ${ }^{37)}, 2$ 章の低合金鋼とは異なり, 予ひずみが水素 吸蔵に及ぼす影響は小さいと考えられる。一方，304では $\mathrm{NH}_{4} \mathrm{SCN}$ 有無の陰極チャージ試験ならびに $98 \mathrm{MPaH}_{2}-85^{\circ} \mathrm{C}-$ $1000 \mathrm{~h}$ の水素ガス中曝露試験では, 予ひずみにより水素濃度 は増加した. これに対して, $98 \mathrm{MPaH}_{2}-250^{\circ} \mathrm{C}-72 \mathrm{~h}$ の水素ガ ス中曝露試験では，予ひずみにより水素濃度は減少した。前 者の条件では水素が試験片の内部まで充填されていないため に，拡散パスとなるマルテンサイト相を有する予ひずみ材の 方が, 水素濃度が多くなったと考えられる ${ }^{15)}$ 。一方, 後者 の条件では前者よりも水素拡散係数が大きく, 試験片の内部 まで水素が完全に充填されているため, 水素の固溶度の小さ いマルテンサイト相を有する予ひずみ材の方が, 水素濃度が 小さくなったと考えられる15)。また，40\%予ひずみ材では $98 \mathrm{MPaH}_{2}-85^{\circ} \mathrm{C}-1000 \mathrm{~h}$ の試験と $98 \mathrm{MPaH}_{2}-250^{\circ} \mathrm{C}-72 \mathrm{~h}$ 試験 で水素濃度がほぼ等しい，本来なら試験温度が高い方が水素 濃度は多いと考えられ，この機構は現時点では不明である. ただし 4 章で後述するように, マルテンサイト系ステンレス 鋼，オーステナイト系材料ともに表面水素濃度で評価する と, $80-300^{\circ} \mathrm{C}$ の温度範囲では水素濃度の変化は小さい場合が 多い.

ここで, Fig. 6-Fig. 7 における水素濃度は, Fig. 5 の水素濃 度分布を有する試験片を用いて分析して得た平均水素濃度で

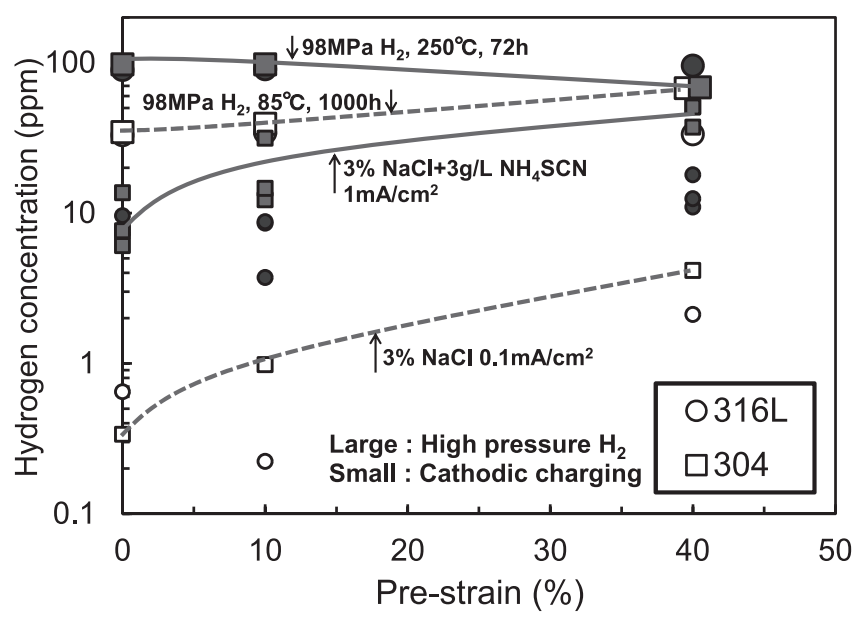

Fig. 7 Effect of applied pre-strain on hydrogen absorption. 
ある。これらの濃度分布の異なる水素添加法の間の水素濃度 を比較するため, Fig. 5 の平均水素濃度が実測值に等しくな るとして, Fig. 5 の最表面(縦軸が1)の水素濃度を求め た ${ }^{32,33)}$ 。陰極チャージ試験では平均水素濃度の 41 倍, $85^{\circ} \mathrm{C}$ の高圧水素ガス中の曝露試験では 2.2 倍が表面水素濃度とな る. $250^{\circ} \mathrm{C}$ の高圧水素ガス中の曝露試験では前述のように試 験片中の水素濃度分布は均一のため, 平均水素濃度と表面水 素濃度は等しい，陰極チャージ試験と高圧水素ガス中の曝露 試験による無ひずみ材の表面水素濃度を Fig. 8 に比較した。 高圧水素ガス環境の表面水素濃度は, Fig. 6 中の適切な院極 チャージの条件の選定により再現可能である。具体的には, Fig. 6 の縦軸の平均水素濃度が 1.5-3 ppm となる条件を選べ ば, Fig. 8 の高圧水素ガス環境の表面水素濃度を再現でき る. すなわち, $3 \% \mathrm{NaCl}$ 水溶液中であれば定電位 $-1.2 \sim-1.5$ $\mathrm{V}$ (vs. 飽和 $\mathrm{Ag} / \mathrm{AgCl}$ 電極) もしくは定電流 0.1-1 mA/ $\mathrm{cm}^{2}$ が, $\mathrm{NH}_{4} \mathrm{SCN}$ を含む水溶液中では定電位 $-1.0 \mathrm{~V}$ (vs. 飽和 $\mathrm{Ag} / \mathrm{AgCl}$ 電極) もしくは定電流 0.1-1 $\mathrm{mA} / \mathrm{cm}^{2}$ が，それぞれ適切な条件 となる。ただし $\mathrm{NH}_{4} \mathrm{SCN}$ を含む溶液中では電位および電流 值が水素濃度の変動が大きい領域に相当し, 水素濃度のばら つきが大きくなる可能性がある。また，これらは最適条件の 例であり, $\mathrm{NH}_{4} \mathrm{SCN}$ 量と電位または電流密度の組合せによ り，他にも最適条件が存在しうる。このようにステンレス鋼 では $3 \% \mathrm{NaCl}$ 水溶液中の陰極チャージにより高圧水素ガス 環境からの水素吸蔵を再現できるが，低合金鋼では 2 章で述 べたように $\mathrm{NH}_{4} \mathrm{SCN}$ を含む溶液を用いるのが望ましい。鋼 種により最適な溶液が異なる理由は現時点では不明である. なお，304 と 316L については，高圧水素ガス環境で吸収さ れた水素による脆化挙動を, 同じ表面水素濃度となる㓌極 チャージ下の引張試験で再現できることが確認されてい る ${ }^{32)}$. 一方, A286(JIS SUH660)やA718などの析出強化型 のオーステナイト系材料では, 高圧水素ガス中の曝露試験と 陰極チャージ試験で, 同じ表面水素濃度下でも脆化特性が一 致しないことも確認されている33).

\section{4. 高 合 金}

高合金も 3 章のステンレス鋼と同様に, 腐食に伴う水素侵

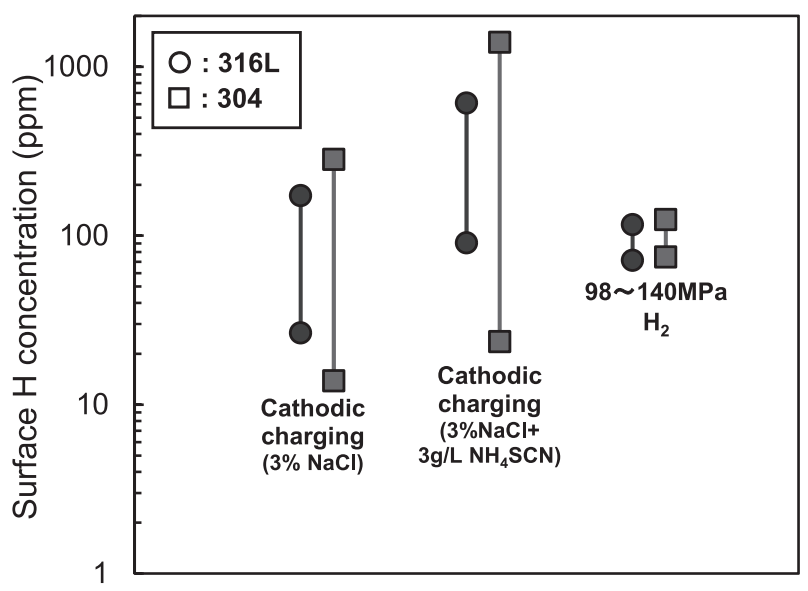

Fig. 8 Comparison in surface hydrogen concentration between hydrogen charging methods.
入の懸念は無いが, 炭素鋼などの腐食し易い異種金属と接触 した場合に，カソードサイト(水素発生サイト)となることに より，水素が侵入する場合がある ${ }^{38)}$ 。また，高圧水素ガス 環境で使用された場合にも水素脆化の危険性がある．低合金 鋼，ステンレス鋼，高 $\mathrm{Ni}$ 合金などの広範囲の材料を用いて， 種々の条件の陰極チャージにより実環境 (油井環境, 高圧水 素ガス環境)における水素吸蔵の再現を試みた例を以下に紹 介する。なお，本章に述べる内容は新規の検討結果である，

供試材には, 降伏強さが $758 \mathrm{MPa}$ 級の $\mathrm{Cr}-\mathrm{Mo}$ 含有鋼 $(0.27 \% \mathrm{C}-1.3 \% \mathrm{Mn}-0.5 \% \mathrm{Cr}-0.1 \% \mathrm{Mo})^{8)}$ および $\mathrm{Cr}-\mathrm{Mo}-\mathrm{V}$ 含有 鋼 $(0.27 \% \mathrm{C}-1 \% \mathrm{Cr}-0.7 \% \mathrm{Mo}-0.1 \% \mathrm{~V})^{7,8)}$, 降伏強さ $668 \mathrm{MPa}$ 級の $13 \%$ の $\mathrm{Cr}$ を含有するマルテンサイト系ステンレス鋼 $(0.2 \% \mathrm{C}-13 \% \mathrm{Cr})^{39)}$, 降伏強さ $862 \mathrm{MPa}$ 級の二相ステンレス 鋼 $\left(25 \% \mathrm{Cr}-7 \% \mathrm{Ni}-3 \% \mathrm{Mo}^{-}-2 \% \mathrm{~W}-0.3 \% \mathrm{~N}\right)^{40)}$, 降伏強さ 758 $\mathrm{MPa}$ 級の高 $\mathrm{Ni}$ 合金 $(25 \% \mathrm{Cr}-31 \% \mathrm{Ni}-3 \% \mathrm{Mo})^{41)}$ の, いずれも 実鋼管を用いた. $\mathrm{Cr}-\mathrm{Mo}$ 鋼, $\mathrm{Cr}-\mathrm{Mo}-\mathrm{V}$ 鋼, $13 \% \mathrm{Cr}$ 鋼は単相 の焼戻しマルテンサイト組織, 二相ステンレス鋼はフェライ トとオーステナイトの二相組織, 高 $\mathrm{Ni}$ 合金は単相のオース テナイト組織を有する. $\mathrm{Cr}-\mathrm{Mo}$ 鋼, $\mathrm{Cr}-\mathrm{Mo}-\mathrm{V}$ 鋼, $13 \mathrm{Cr}$ 鋼か らは厚さ $2 \mathrm{~mm}$, 二相ステンレス鋼と高 $\mathrm{Ni}$ 合金からは厚さ $0.5 \mathrm{~mm}$ の薄板試験片を採取した。試験片の表面を 600 番工 メリー紙まで湿式研磨後, 水素チャージ試験に供した。試験 後の試験片は冷凍保管し, 昇温速度 $10^{\circ} \mathrm{C} / \mathrm{min}$ で昇温脱離水 素分析を行った. 分析器には四重極分析装置を用いた. $\mathrm{Cr}-\mathrm{Mo}$ 鋼, $\mathrm{Cr}-\mathrm{Mo}-\mathrm{V}$ 鋼, $13 \mathrm{Cr}$ 鋼については, マルテンサイ

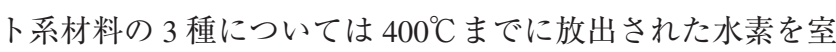
温拡散性水素と解釈した。 二相ステンレス鋼と高 $\mathrm{Ni}$ 合金に ついては $600^{\circ} \mathrm{C}$ までに放出された水素を積分し水素濃度を求 めた。

まず，陰極チャージ試験には $25^{\circ} \mathrm{C} の 3 \% \mathrm{NaCl}$ 水溶液に最 大 $30 \mathrm{~g} / \mathrm{L}$ の $\mathrm{NH}_{4} \mathrm{SCN}$ を加えた溶液を用いて, 保持電位 -1.2 $\mathrm{V}$ (vs. 飽和 $\mathrm{Ag} / \mathrm{AgCl}$ 電極) で $48 \mathrm{~h}$ の定電位試験を行い, その 後に昇温水素分析を行った。ここで 3 章で述べたように，水 素の拡散が遅い材料では，今回の陰極チャージ時間 $(48 \mathrm{~h})$ で は試験片の内部まで水素が充填されていない可能性がある. 各素材の $25^{\circ} \mathrm{C}$ における水素拡散係数 $D$ を, Cr-Mo 鋼は $1 \times$ $10^{-5} \mathrm{~cm}^{2} / \mathrm{s}^{4)}, \mathrm{Cr}-\mathrm{Mo}^{-} \mathrm{V}$ 鋼は $3 \times 10^{-6} \mathrm{~cm}^{2} / \mathrm{s}^{4)}, 13 \mathrm{Cr}$ 鋼は $3 \times$ $10^{-7} \mathrm{~cm}^{2} / \mathrm{s}^{39)}$, 二相ステンレス鋼は $3 \times 10^{-9} \mathrm{~cm}^{2} / \mathrm{s}^{40)}$, 高 $\mathrm{Ni}$ 合金は $1 \times 10^{-11} \mathrm{~cm}^{2} / \mathrm{s}^{41,42)}$ とし，3 章と同様の方法で Fig. 5 のような試験片中の水素濃度分布を計算した。 ここで二相ス テンレス鋼については, 文献中 ${ }^{40)}$ の陰極チャージ下におけ る吸蔵水素濃度の時間変化と飽和值から, 水素拡散係数を見 積もっている，計算の結果, $\mathrm{Cr}-\mathrm{Mo}$ 鋼, $\mathrm{Cr}-\mathrm{Mo}-\mathrm{V}$ 鋼, $13 \mathrm{Cr}$ 鋼では水素は完全に試験片中に充填され, 二相ステンレス鋼 ではわずかに水素濃度分布が生じ，高 $\mathrm{Ni}$ 合金では試験片の 表面付近にしか水素が吸蔵されていないと推定された。水素 の充填率 (Fig. 5 の最表層の水素濃度に対する平均水素濃度 の比率) は, $\mathrm{Cr}-\mathrm{Mo}$ 鋼， $\mathrm{Cr}-\mathrm{Mo}-\mathrm{V}$ 鋼， $13 \mathrm{Cr}$ 鋼では $100 \%$ 二 二 相ステンレス鋼では $98.6 \%$, 高 $\mathrm{Ni}$ 合金ではわずかに $8.5 \%$ で あった，水素濃度の分布と実測された試験片中の平均水素濃 度から表面の水素濃度を求め, 主要な合金元素の含有量 $(\mathrm{Cr}$, $\mathrm{Ni}$, Mo の合計量, mass\%)で整理して Fig. 9 に示す. 同じ陰 
極チャージ条件では, $\mathrm{Cr}-\mathrm{Mo}$ 鋼に比べ $\mathrm{Cr}-\mathrm{Mo}^{-}-\mathrm{V}$ 鋼の水素濃 度は 1 桁大きく，これは 2 章でも述べたように微細な $\mathrm{V}$ 系 炭化物による水素トラップ効果が表れていると考えられる. $13 \mathrm{Cr}$ 鋼は $\mathrm{Cr}-\mathrm{Mo}$ 鋼や $\mathrm{Cr}-\mathrm{Mo}-\mathrm{V}$ 鋼よりもさらに多くの水素 を吸蔵し, これは固溶合金元素による水素トラップ効果 ${ }^{39)}$ が理由と推定される。 二相ステンレス鋼 (Duplex Stainless Steel, DSS) と高 Ni 合金 (Ni alloy) は, $13 \mathrm{Cr}$ 鋼よりもさらに 多くの水素を吸蔵した。これは, 体心立方 (body centered cubic, bcc) 構造のマルテンサイト相よりも, fcc 構造のオー ステナイト相の方が水素の固溶度が大きい ${ }^{1)}$ ためと考えられ る。また, 各材料とも溶液中の $\mathrm{NH}_{4} \mathrm{SCN}$ 量が増すと吸蔵水 素濃度は増加した。ただし, $\mathrm{NH}_{4} \mathrm{SCN}$ 量に対する水素濃度の 増加割合は, $\mathrm{Cr}-\mathrm{Mo}$ 鋼が最も比率としては最も大きく, 次 が $\mathrm{Cr}-\mathrm{Mo}-\mathrm{V}$ 鋼であり， $13 \mathrm{Cr}$ 鋼，二相ステンレス鋼， $\mathrm{Ni}$ 基 高合金では小さくなった，2 章の Fig. 3 では, $\mathrm{Cr}-\mathrm{Mo}$ 鋼無ひ ずみ材では水素濃度が少ないチャージ法に比べ, 水素濃度が 多いチャージ法による水素濃度の増加代が大きく, $\mathrm{Cr}-\mathrm{Mo}$ 鋼予ひずみ材や $\mathrm{Cr}-\mathrm{Mo}-\mathrm{V}$ 鋼では増加代が小さい. この理由 は 2 章で述べたように，異なるトラップエネルギーを持つサ イト間の水素濃度の分配の違いで説明できる. Fig. 9 中のマ ルテンサイト系の 3 種の材料に関しても同様の機構が働いた と推定され, $\mathrm{Cr}-\mathrm{Mo}-\mathrm{V}$ 鋼や $13 \mathrm{Cr}$ 鋼などの水素トラップ能の 強い鋼種では，通常鋼 $(\mathrm{Cr}-\mathrm{Mo}$ 鋼)に比べマイルドな水素添 加条件でも多くの水素を吸蔵し, $\mathrm{NH}_{4} \mathrm{SCN}$ の影響が小さく表 れたと推定される。 また, Fig. 9 中で二相ステンレス鋼や $\mathrm{Ni}$ 基合金では水素濃度に及ぼす $\mathrm{NH}_{4} \mathrm{SCN}$ の影響が他の材料に 比べ小さかったが，3章で述べたステンレス鋼も2 章の低合 金鋼に比べ, 水素濃度の $\mathrm{NH}_{4} \mathrm{SCN}$ 量への依存性が小さかっ た。この機構は現時点では不明だが，オーステナイト相中の 水素の拡散の活性化エネルギーは後述のように 47-54 kJ/mol 程度と報告されており ${ }^{35,41)} ， 2$ 章で述べたマルテンサイト系 材料の各種サイトによるトラップエネルギーよりも大きいこ とから, 外部環境の過酷度 ( $\mathrm{NH}_{4} \mathrm{SCN}$ 量) に対する材料中の水 素濃度の変化代が小さくなっている可能性がある。なお, Fig. 9 中には後述する高圧水素ガス中の曝露試験による吸蔵 水素濃度も併記したが, 各材料の吸蔵水素濃度の大小の順列 は，陰極チャージ試験と同様であった。 また，両者の方法間 の水素濃度の対応については本章の末尾で後述する.

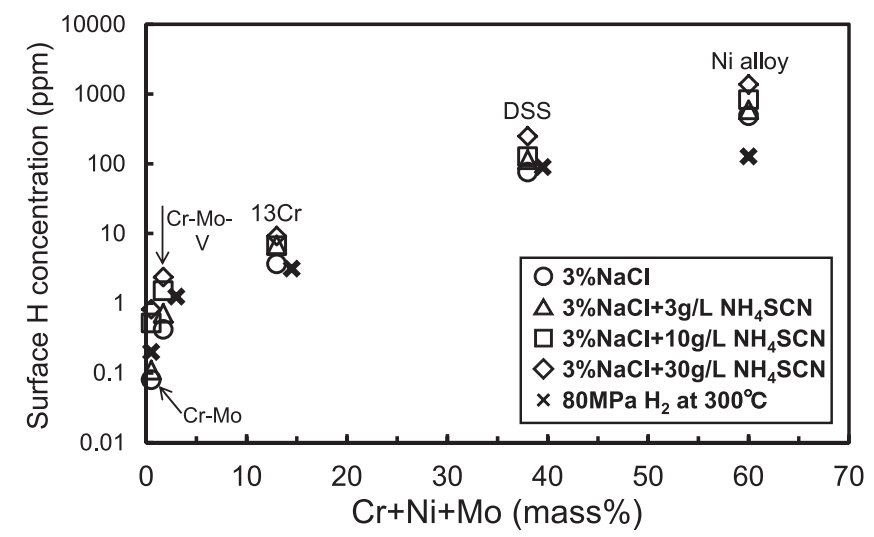

Fig. 9 Effect of the amount of $\mathrm{NH}_{4} \mathrm{SCN}$ on surface hydrogen concentration under cathodic hydrogen charging.
実環境における吸蔵水素濃度に関して，2-3 章では大気腐 食環境および高圧水素ガス環境を想定した。一方, 本章で用 いた材料は油井管としても用いられるため, 油井 (模擬) 環境 において報告されている水素濃度と Fig. 9 の陰極チャージに よる水素濃度を以下のように比較した. $\mathrm{Cr}-\mathrm{Mo}^{-} \mathrm{V}$ 鋼につい ては，常温の 1-15 bar の湿潤硫化水素環境の自然浸漬で 2.3 $\mathrm{ppm}^{7)}, 100 \mathrm{bar}-107^{\circ} \mathrm{C}$ の高温高圧硫化水素環境の自然浸漬で $1.5 \mathrm{ppm}^{8)}$ との報告例があり, Fig. 9 のように 10-30 g/L の $\mathrm{NH}_{4} \mathrm{SCN}$ を添加した溶液中の陰極チャージでこれらの水素吸 蔵を再現できる。 $13 \mathrm{Cr}$ 鋼については, 1 barの湿潤硫化水素 環境中の自然浸漬で最大 $5 \mathrm{ppm}$ の水素吸蔵が確認されてお $\eta^{43)}$ ，3-10 g/L の $\mathrm{NH}_{4} \mathrm{SCN}$ を添加した溶液中の陰極チャー ジでこの水素吸蔵が再現できる. 二相ステンレス鋼の実鋼管 では, 炭素鋼との異種金属接触で $30 \mathrm{ppm}$ の水素吸蔵が報告 されており ${ }^{38)}, \mathrm{NH}_{4} \mathrm{SCN}$ を添加しない $3 \% \mathrm{NaCl}$ 水溶液中の 陰極チャージでこの水素濃度が再現できる，高 $\mathrm{Ni}$ 合金の炭 素鋼との異種金属接触による水素脆化試験では表面水素濃度 に換算し $80 \mathrm{ppm}$ の水素吸蔵が推定されており ${ }^{40)}$, Fig. 9 の $\mathrm{NH}_{4} \mathrm{SCN}$ を添加しない $3 \% \mathrm{NaCl}$ 水溶液中の陰極チャージで はこれより多い量の表面水素濃度となる。記は保持電位を $-1.2 \mathrm{~V}(\mathrm{vs}$. 飽和 $\mathrm{Ag} / \mathrm{AgCl}$ 電極) に固定した場合の最適 $\mathrm{NH}_{4} \mathrm{SCN}$ 量であるが, 2-3 章で述べたように電位や電流密度 を変化させれば, 実環境の再現条件は他にも存在すると考え られる。

Fig. 9 の表面水素濃度 $C_{0}$ と水素拡散係数 $D$ の積から, 水 素透過係数 $C_{0} D$ を見積もることができる. この值は, 水素 透過試験を行った際の水素の透過速度に相当する. Fig. 10 に $C_{0} D$ を合金元素含有量で整理した. $\mathrm{Cr}-\mathrm{Mo}$ 鋼, $\mathrm{Cr}-\mathrm{Mo}-\mathrm{V}$ 鋼, $13 \mathrm{Cr}$ 鋼は, 同じ水素チャージ条件 ( $\mathrm{NH}_{4} \mathrm{SCN}$ 量)では $C_{0} D$ は同程度である.すなわち, $\mathrm{Cr}-\mathrm{Mo}-\mathrm{V}$ 鋼や $13 \mathrm{Cr}$ 鋼は水 素トラップ効果のため $\mathrm{Cr}-\mathrm{Mo}$ 鋼よりも水素濃度 $C_{0}$ は 1 桁大 きくなるが, 同じ割合で $D$ が小さくなる，水素トラップサ イトの有無に関わらず, 同じ水素チャージ条件では一般鋼と 水素トラップ鋼の水素透過係数は等しくなる現象は過去に報 告されている44,45). この理由は, 水素トラップサイトの体積 が充分小さい場合には, 格子間固溶水素(水素透過の流量を 担う水素) とトラップされた水素が局所平衡を保ち, 見かけ 上水素で埋まったトラップサイトは水素の流束に影響しなく

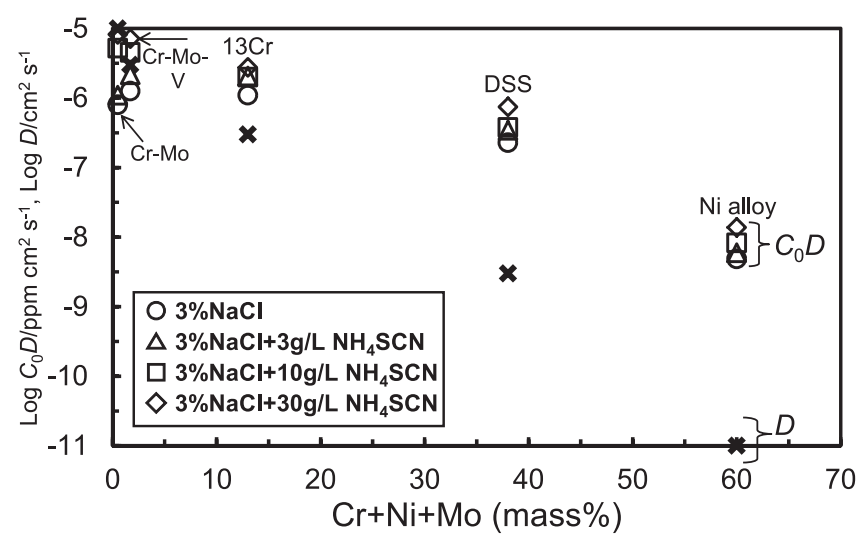

Fig. 10 Comparison in hydrogen permeability $\left(C_{0} D\right)$ between the investigated materials. 
なることと考えられる ${ }^{46,47)}$. 一方，二相ステンレス鋼および $\mathrm{Ni}$ 基合金では, マルテンサイト系材料に比べ $C_{0} D$ は低下し た。すなわち，オーステナイト相が含まれることで， $C_{0} D$ は 低下する. Fig. 10 には前述の各材料の水素拡散係数を併記 したが，高 $\mathrm{Ni}$ 合金は $\mathrm{Cr}-\mathrm{Mo}$ 鋼と比べると，吸蔵水素濃度 $C_{0}$ は 3-4 桁大きくなるのに対し, 水素拡散係数 $D$ は 6 桁小 さくなることが, $C_{0} D$ が極端に小さくなった理由である。こ の整理はオーステナイト系材料では水素の透過速度が極めて 小さく，水素透過試験が難しいことを示している. 304 の常 温における水素透過試験では厚さ $30 \mu \mathrm{m}$ の薄膜が用いられ た例もある ${ }^{35)}$.

また, 以下に高圧水素ガス環境における水素吸蔵挙動につ いて述べる．2-3 章では代表的な条件における水素濃度を用 いたが, 高圧水素ガス環境からの吸蔵水素濃度は水素ガス圧 や温度に依存し変化する可能性がある。 そこで本章では前述 の陰極チャージ試験と同じ供試材を用いて, 常温〜 $300^{\circ} \mathrm{C}$, 圧力 20-80 MPa の高圧水素ガス環境中に $48 \mathrm{~h}$ の間曝露し, 昇温脱離分析により吸蔵水素濃度を測定した。陰極チャージ 試験と同様に, $\mathrm{Cr}-\mathrm{Mo}$ 鋼, $\mathrm{Cr}-\mathrm{Mo}-\mathrm{V}$ 鋼, $13 \mathrm{Cr}$ 鋼では厚さ 2 $\mathrm{mm}$, 二相ステンレス鋼, $316 \mathrm{~L}$, 高 $\mathrm{Ni}$ 合金では厚さ $0.5 \mathrm{~mm}$ の試験片を用いた．Fig. 11 に $20 \mathrm{MPa} の$ 条件における各鋼種 の水素吸蔵に及ぼす温度の影響を示す。いずれの鋼種も, 温 度上昇に伴い水素濃度は増加した。ただし，いずれの鋼種も 常温では水素吸蔵はほとんど起こらず，それぞれの鋼種にお いて水素吸蔵が起こり始める臨界温度が存在した。臨界温度 は $\mathrm{Cr}-\mathrm{Mo}$ 鋼, $\mathrm{Cr}-\mathrm{Mo}^{-} \mathrm{V}$ 鋼, $13 \mathrm{Cr}$ 鋼, 二相ステンレス鋼 (DSS), 316L では $80^{\circ} \mathrm{C}$, 高 $\mathrm{Ni}$ 合金 $\left(\mathrm{Ni}\right.$ alloy) では $50^{\circ} \mathrm{C} て ゙$ あった. Fig. 12 に $80 \mathrm{MPa}$ の条件の試験結果を示す. Fig. 11 の $20 \mathrm{MPa}$ 環境と比べるとより多くの水素が吸蔵された。 ま た, 水素吸蔵が起こり始める臨界温度は, Cr-Mo 鋼,

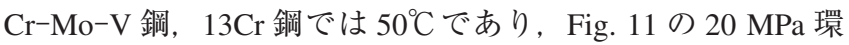
境よりも臨界温度は低くなった。二相ステンレス鋼 (DSS), 316L，高 $\mathrm{Ni}$ 合金 (Ni alloy)の臨界温度は明確でないが, 見か け上は常温から連続的に水素が吸蔵された。低合金鋼 $\left(\mathrm{Cr}-\mathrm{Mo}^{-} \mathrm{V}\right.$ 鋼) において, 常温では水素吸蔵が起こりにくく, 水素吸蔵が起こり始める臨界温度が存在することは過去の検 討でも確認されており ${ }^{10)}$, 試験片表面の酸化物皮膜が水素 分子の解離反応の障壁になる機構が推察されている.ただ

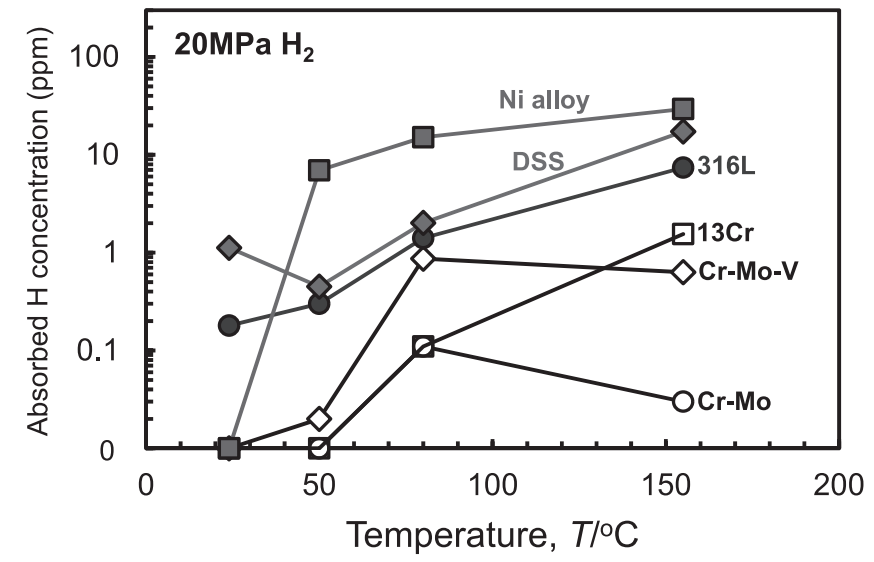

Fig. 11 Effect of test temperatures on hydrogen absorption in high pressure gaseous hydrogen at $20 \mathrm{MPa}$.
し, 水素ガス中で塑性変形を与えると, 常温以下の温度 $\left(-40^{\circ} \mathrm{C}\right)$ でも水素吸蔵が起こることも確認されている10).

3 章および本章の前半でも述べたように, fcc 系の材料は bcc 系の材料に比べて水素の拡散が遅く, 今回の曝露条件に よっては試験片の中心部まで水素が充填されていない可能性 がある．316L および高 $\mathrm{Ni}$ 合金において，3 章の方法で試験 片の板厚方向の水素濃度分布を計算した。 ここで，316L の 水素拡散係数 $D$ は 3 章の通りに $4.41 \times 10^{-3} \exp (-53510 / R T)$ $\left(\mathrm{cm}^{2} / \mathrm{s}\right)$, 高 $\mathrm{Ni}$ 合金は $1.87 \times 10^{-3} \exp (-47070 / R T)\left(\mathrm{cm}^{2} / \mathrm{s}\right)^{41)}$ とした， $R$ は気体定数 $(8.31 \mathrm{~J} / \mathrm{mol}), T$ は温度 $(\mathrm{K})$ である。曝 露試験温度に応じ，表面水素濃度を計算すると Fig. 13 のよ うになる。水素の充填率は, $316 \mathrm{~L}$ では $200^{\circ} \mathrm{C}$ 以上, 高 $\mathrm{Ni}$ 合 金では $150^{\circ} \mathrm{C}$ 以上でほほ $100 \%$ との計算結果となった。 $316 \mathrm{~L}$ では $20 \mathrm{MPa}$ 環境では傾向が顕著でないが， $80 \mathrm{MPa}$ 環境では $150^{\circ} \mathrm{C}$ 以上で表面水素濃度が急増し，200-300 $\mathrm{C}$ で飽和した。 ただし, Fig. 13 中の $316 \mathrm{~L}$ の水素圧 $80 \mathrm{MPa}$-温度 $80^{\circ} \mathrm{C}$ 条件に おける水素濃度は, 3 章で紹介した水素圧 $98 \mathrm{MPa}$-温度 $85^{\circ} \mathrm{C}$ 条件における水素濃度に比べ少なかった。一方，高 $\mathrm{Ni}$ 合金 (Ni alloy)では，表面水素濃度で整理すると $20 \mathrm{MPa}, 80 \mathrm{MPa}$ 中曝露試験ともに，温度依存性があまり見られなかった。す なわち, 高 $\mathrm{Ni}$ 合金では水素侵入は比較的低温 (常温 $50^{\circ} \mathrm{C}$ ) から起こっているが, 低温では試験片中に水素が充填されて いないため, Fig. 11-Fig. 12のように温度上昇に伴い水素濃 度が増加しているように見えると推定される．高 $\mathrm{Ni}$ 合金は

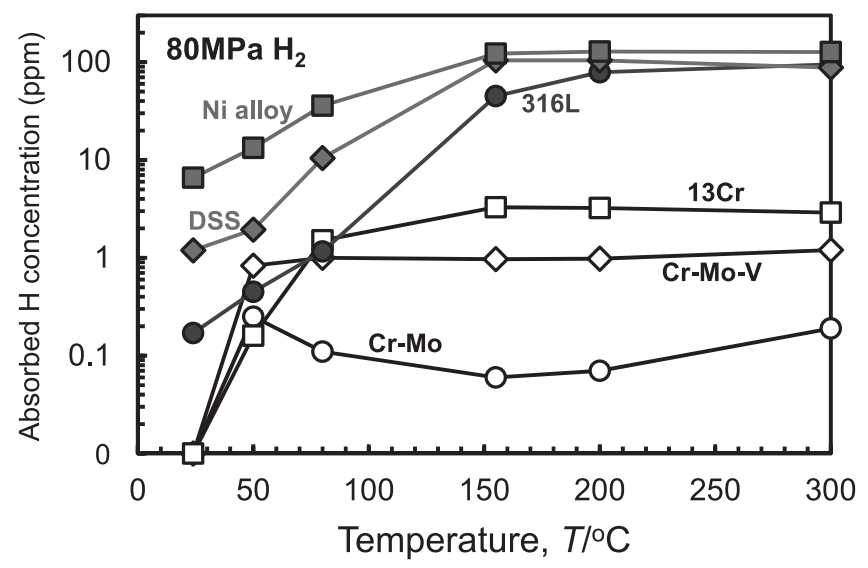

Fig. 12 Effect of test temperature on hydrogen absorption in high pressure gaseous hydrogen at $80 \mathrm{MPa}$.

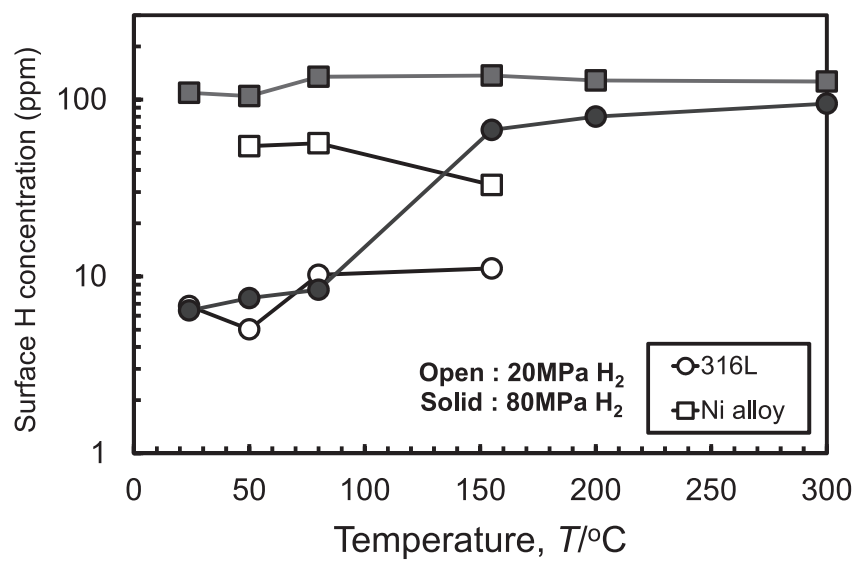

Fig. 13 Effect of test temperature on surface hydrogen concentration in high pressure gaseous hydrogen. 
316L や二相ステンレス鋼と同程度の Cr を含有するため, 表 面にはこれらのステンレス鋼と同程度の厚さの酸化物皮膜を 形成していると考えられるが, Ni が水素侵入の触媒として 働き, Fig. 13 の挙動を示した可能性が考えられる.

Fig. 9 中には, Fig. 11-Fig. 12 で測定された最大水素濃度 (水素圧 $80 \mathrm{MPa}$-温度 $300^{\circ} \mathrm{C}$ ) を陰極チャージによる水素濃度 と比較して示している. マルテンサイト系材料 3 種と二相ス テンレス鋼については, 適切な量の $\mathrm{NH}_{4} \mathrm{SCN}$ を添加した水 溶液中の陰極チャージにより，この高圧水素ガス環境におけ る水素侵入量を再現できる。すなわち, $\mathrm{Cr}-\mathrm{Mo}$ 鋼では 3-10 $\mathrm{g} / \mathrm{L}, \quad \mathrm{Cr}-\mathrm{Mo}-\mathrm{V}$ 鋼では $10 \mathrm{~g} / \mathrm{L}, \quad 13 \mathrm{Cr}$ 鋼では $\mathrm{NH}_{4} \mathrm{SCN}$ 添加無 し, 二相ステンレス鋼では 0-3 g/L が適切な添加量である. 一方, 高 $\mathrm{Ni}$ 合金では $\mathrm{NH}_{4} \mathrm{SCN}$ 無しの溶液を用いても陰極 チャージの方が多くの水素を吸蔵し, 水素濃度を下げるため には電位もしくは電流密度の調整がさらに必要である。ま た, 水素ガス環境の水素圧や温度に対応して Fig. 11-Fig. 12 のように各材料の水素濃度が変化した場合には, それらを再 現するには $\mathrm{NH}_{4} \mathrm{SCN}$ 量および電位, 電流密度の最適化が必 要と考えられる.

\section{5. 結言}

本報では，低合金鋼，ステンレス鋼，高合金を用いて種々 の方法で水素添加を行い, 昇温脱離分析により水素の吸蔵挙 動を比較した研究例を紹介した。いずれの材料においても, 適切な水溶液の選定や, 陰極チャージの際のカソード電流密 度や電位の設定により, 実環境における水素吸蔵を再現でき る.ただし, 低合金鋼では材質と水素濃度に応じて, 水素の トラップ状態が変わる場合があることに注意を要する。逆に オーステナイト系の材料では, 見かけ上の昇温脱離曲線の違 いは試験片中の初期水素濃度分布で決まっており, 水素卜 ラップ状態が異なるわけではない点に注意を要する。これら の知見が, 今後適切な水素脆化評価法に活用されることが期 待される。

文 献

1) Y. Fukai, K. Tanaka and H. Uchida: Suiso-to-Kinzoku, (Uchida Rokakuho Publishing Co., Ltd., Tokyo, 1998).

2) M. Nagumo: Fundamentals of Hydrogen Embrittlement, (Uchida Rokakuho Publishing Co., Ltd., Tokyo, 2008).

3) S. Matsuyama: Delayed Fracture, (The Nikkan Kogyo Shimbun Ltd., Tokyo, 1973).

4) T. Kushida, H. Matsumoto, N. Kuratomi, T. Tsumura, F. Nakasato and T. Kudo: Tetsu-to-Hagané 82 (1996) 297-302.

5) S. Yamasaki and T. Takahashi: Tetsu-to-Hagané 83 (1997) 454-459.

6) Fédération Internationale de la Précontrainte: Report on Prestressing Steel 5, (1980), Sep., 1.

7) T. Omura, K. Kobayashi and M. Ueda: Proc. Corrosion 2009, (NACE Internatonal, 2009) Paper No. 09102.

8) K. Kobayashi, T. Omura, A. Souma, T. Ohe, H. Amaya and M. Ueda:
Corrosion 74 (2018) 509-519.

9) E. Takeuchi, Y Furuya, H. Hirukawa, T. Matsuo and S. Matsuoka: Trans. Jpn. Soc. Mech. Eng. A 70 (2013) 1030-1040.

10) T. Omura, J. Nakamura and K. Kobayashi: Zairyo-to-Kankyo 63 (2014) 528-534.

11) K. Takai, S. Takagi and T. Omura: Bull. Iron Steel Inst. Jpn. 19 (2014) 911-919.

12) T. Omura et al.: Testu-to-Hagané 100 (2014) 1289-1297.

13) K. Ebihara, T. Iwamoto, Y. Matsubara, H. Yamada, T. Okamura, W. Urushihara and T. Omura: ISIJ Int. 54 (2014) 153-159.

14) H. Mizuno, J. Sakai, K. Yokoyama, H. Suzuki, M. Imade, T. Omura and R. Okuma: Fundamental construction for hydrogen embrittlement, (ISIJ, Tokyo, 2013) pp. 15-20.

15) M. Enomoto, L. Cheng, H. Mizuno, Y. Watanabe, T. Omura, J. Sakai, K. Yokoyama, H. Suzuki and R. Okuma: Met. Mat. Trans. 1E (2014) 331-340.

16) Japanese Automobile Standard Organization (JASO) M 609, (1991).

17) S. Takagi and Y. Toji: ISIJ Int. 52 (2012) 329-331.

18) T. Doshida, K. Takai and M. Ichiba: Zairyo-to-Kankyo 61 (2012) 249-256.

19) H.R. Gray: ASTM STP 543 (1974) 133-151.

20) R.P. Jewett, R.J. Walter, W.T. Chandler and R.P. Frohmberg: NASA CR-2163 (1973)

21） W.T. Chandler and R.J. Walter: ASTM STP 543 (1974） 170-197.

22) G. Han, J. He, S. Fukuyama and K. Yokogawa: Acta Mater. 46 (1998) 4559-4570.

23) D. Sun, G. Han, S. Vaodee, S. Fukuyama and K. Yokogawa: Mater. Sci. Technol. 17 (2001) 302-308.

24) T. Miyamoto, T. Matsuo, N. Kobayashi, Y. Mukaie and S. Matsuoka: Trans. Jpn. Soc. Mech. Eng. A 78 (2012) 531-546.

25) T. Matsumoto, H. Itoga, S. Hirabayashi, M. Kubota and S. Matsuoka: Trans. Jpn. Soc. Mech. Eng. A 79 (2013) 1210-1225.

26) S. Matsuoka: J. HTSJ 48(203) (2009) 7-19.

27) T. Matsuo, J. Yamabe, Y. Fukushima, S. Matsuoka and Y. Murakami: J. Soc. Mater. Sci. Japan 59 (2010) 924-931.

28) N. Tajima, A. Orita, T. Matsuo, Y. Yamaguchi, J. Yamabe and S. Matsuoka: Trans. Jpn. Soc. Mech. Eng. 78 (2012) 1173-1188.

29) M. Imade, L. Zhang, T. Iijima, S. Fukuyama and K. Yokogawa: J. Japan Inst. Metals 73 (2009) 245-250.

30) L. Zhang, M. Imade, B. An, M. Wen, T. Iijima, S. Fukuyama and K. Yokogawa: Tetsu-to-Hagané 99 (2013) 294-301.

31) T. Omura, K. Kobayashi, M. Miyahara and T. Kudo: Zairyo-toKankyo 55 (2006) 139-145.

32) T. Omura, K. Kobayashi, M. Miyahara and T. Kudo: Zairyo-toKankyo 55 (2006) 537-543.

33) T. Omura, J. Nakamura, H. Hirata, K. Jotoku, M. Ueyama, T. Osuki and M. Terunuma: ISIJ Int. 56 (2016) 405-412.

34) J. Crank: The Mathematics of Diffusion, (Clarendon Press, Oxford, 1975).

35) Y. Sakamoto and H. Katayama: J. Japan Inst. Metals 46 (1982) 805814.

36) K. Takai, K. Murakami, N. Yabe, H. Suzuki and Y. Hagihara: J. Japan Inst. Metals 72 (2008) 448-456.

37) K. Takai: Trans. Jpn. Soc. Mech. Eng. A 70 (2004) 1027-1035.

38) P. Sentance: Proc. Duplex Stainless Steels '91 (1991)

39) T. Kushida and T. Kudo: Materia Japan 33 (1994) 932-939.

40) T. Kamimura, H. Miyuki, K. Ogawa, J. Imamura, H. Kita and H. Nakano: Rust Prevention \& Control Japan 53 (2009) 9-15.

41) M. Sagara, T. Tomio, T. Otome, N. Sawawatari, T. Omura and H. Amaya: Proc. Corrosion 2016, (NACE Internatonal, 2016) Paper No.7847.

42) J. Xu, X.K. Sun, W.X. Chen and Y.Y. Li: Acta Metall. Mater. 41 (1993) 1455-1499.

43) M. Ueda, T. Kushida, K. Kondo and T. Kudo: Proc. Corrosion 92, (NACE Internatonal, 1992) Paper No.55.

44) T. Hara: Zairyo-to-Kankyo 60 (2011) 259-264.

45) T. Omura, T. Kushida, F. Nakasato, S. Watanabe and I. Oyamada: Tetsu-to-Hagané 91 (2005) 478-484.

46) R.A. Oriani: Acta Metall. 18 (1970) 147-157.

47) G.M. Pressouyre and I.M. Bernstein: Corros. Sci. 18 (1978) 819-833. 